\title{
H3.Y wt Allele
}

National Cancer Institute

\section{Source}

National Cancer Institute. H3.Y wt Allele. NCI Thesaurus. Code C155737.

Human H3.Y wild-type allele is located in the vicinity of 5p15.1 and is approximately $0.6 \mathrm{~kb}$ in length. This allele, which encodes histone H3.Y protein, may play a role in the chromatin structure and transcriptional regulation. 